\title{
2001 fissure-forming eruption of Inie Lika volcano, central Flores, Indonesia
}

\author{
Hirofumi MuraOKA ${ }^{1}$, Kasumi YasukAWA ${ }^{1}$, Minoru URAI ${ }^{2}$, Masaaki TAKAHASHI ${ }^{3}$, \\ Asnawir NASUTION ${ }^{4}$ and Isao TAKASHIMA ${ }^{5}$
}

\begin{abstract}
Hirofumi Muraoka, Kasumi Yasukawa, Minoru Urai, Masaaki Takahashi, Asnawir Nasution and Isao TAKASHIMA (2002) 2001 fissure-forming eruption of Inie Lika volcano, central Flores, Indonesia. Bull. Geol. Surv. Japan, vol. 53 (2/3), p. 175-182, 5 figs.
\end{abstract}

\begin{abstract}
A phreato-magmatic eruption occurred at the Inie Lika volcano, Flores Island, Indonesia during January 11-16, 2001 after 95 years of quiescence. This event and consequent fissure formation were described. Inie Lika volcano forms a northern part of the Bajawa Cinder Cone Complex extending over $16 \mathrm{~km}$ in the NNW-SSE direction. Ash fall continued for six days and steam discharge continued for two months after the incipience of the eruption. It should be noted that the eruption formed a $N 16^{\circ} \mathrm{W}$ trending fissure, about $20 \mathrm{~m}$ wide and $300 \mathrm{~m}$ long, suggesting tensile rifting caused by a thin magmatic dike invasion into a shallow depth.
\end{abstract}

\section{Introduction}

A phreato-magmatic eruption started to occur at Inie Lika volcano, Flores Island, eastern Indonesia at 19:15 on January 11, 2001. Ash fall continued for six days and steam discharge continued for two months after the incipience of the eruption. The volcano does not have a universally accepted name. It has been referred to as Inerika (1: 25,000 scale topographic map "Lokangeko", Badan Koordinasi Survey dan Pemetaan Nasional, 1993), Inielika (Ahmad, 2001a, 2001b) or Inie Lika (Neumann van Padang, 1951; Pribadi et al., 2000) depending on a given literature. This paper shall use the name Inie Lika hereinafter. The eruption occurred after 95 years of quiescence since the last phreatic eruption recorded in 1905 (Neumann van Padang, 1951).

Ahmad (2001a, 2001b) summarizes the 2001 eruption in the Volcanic Activity Reports at the Web site of Smithsonian National Museum of Natural History. However, the reports do not mention the fissure formation by the eruption that might be critically important for a better understanding of the genesis of the Bajawa Cinder Cone Complex (Muraoka et al., 1999a, 1999b, 2000a, 2000b, 2000c,

\footnotetext{
${ }^{1}$ Institute for Geo-Resources and Environment, GSJ

${ }^{2}$ Institute of Geoscience, GSJ

${ }^{3}$ Research Center for Deep Geological Environments, GSJ

${ }^{4}$ Directorate of Volcanology and Geological Hazard Mitigation. JI. Diponegoro No.57, Bandung, 40122 Indonesia

${ }^{5}$ Akita University. Tegatagakuen 1-1, Akita, 010-8502 Japan
}

2001a). We have visited the eruption center of the Inie Lika volcano on August 29, 1999 before the eruption, January $21-22,2001$ ten days after the eruption while it was actively steaming and July 20, 2001 after the steam discharge ceased. Based on these observations, we have realized that one of the most conspicuous morphological changes by this eruption was the new formation of a $\mathrm{N} 16^{\circ} \mathrm{W}$ trending fissure, about $20 \mathrm{~m}$ wide and $300 \mathrm{~m}$ long. This short paper describes the fissure formation by the 2001 eruption and discusses its significance to the evolution of the Bajawa Cinder Cone Complex.

\section{Bajawa Cinder Cone Complex}

Figure 1 shows a JERS-1 SAR image taken on February 3, 1996 five years before the eruption (Urai et al., 2002). Inie Lika volcano is situated immediately north of Bajawa the capital city of Ngada District, Nusa Tenggara Timur Province and composed of at least 25 cinder cones over $10 \mathrm{~km}$ in the north-south direction (Fig. 1). To the south, the Bobo volcano is also composed of at least 10 cinder cones. Both Inie Lika and Bobo volcanoes are traditionally distinguished because of the isolation of major edifices. However, Figure 1 shows that small cinder cones are also aligned between the edifices, and all these elements form an almost continuous alignment over $16 \mathrm{~km}$. To the southeast, at least two rows of NW-SE trending cinder cone alignments are also found as other branches. When we connect all the cinder cone alignments, they look

Keywords: eruption, fissure, Inie Lika volcano, Inielika volcano, Inerika volcano, cinder cone, dike, Flores, Indonesia 
like a radial dike complex at a depth. Chemical compositions of rock samples taken from these cinder cones are remarkably homogeneous calc-alkaline andesite respective to their spatial extent, suggesting connected dikes at a depth (Muraoka et al., 1999a, 1999b, 2000a, 2000b, 2000c, 2001a). Therefore, away from the major edifices such as Inie Lika and Bobo volcanoes, we can collectively name those cinder cones as the Bajawa Cinder Cone Complex that extends over $16 \mathrm{~km}$ in the NNW-SSE direction (Fig. 1; Muraoka et al., 2002, this issue). This complex is not only situated in our study area of the ongoing Indonesia-Japan bilateral cooperation program, "Research Cooperation Project on the Exploration of Small-scale Geothermal Resources in the Eastern Part of Indonesia" (Muraoka et al., 1998), but also is evaluated to be a heat source of the major geothermal systems in the study area (Muraoka et al., 1999a, 1999b, 2000a, 2000b, 2000c, 2001a). The Inie
Lika volcano forms the northern part of the Bajawa Cinder Cone Complex (Fig. 1).

\section{2001 eruption events}

Detailed descriptions of the 2001 eruption events of Inie Lika volcano are beyond the scope of this paper because our observations were not stationary. Based on the stationary observations from the Inie Lika Volcano Observatory, Ahmad (2001a) details the eruption processes of the Inie Lika volcano during the middle of January 2001. We shall briefly summarize here for an understanding of the eruption process. The first explosion event started to occur at 19:15 on January 11, 2001. Ahmad (2001a) described that the ejected ash of this event covered Bajawa City, $8 \mathrm{~km}$ south from the eruption center, with an ash layer less than $0.5 \mathrm{~mm}$. Three explosions also occurred about 7:00 on January 13, 2001

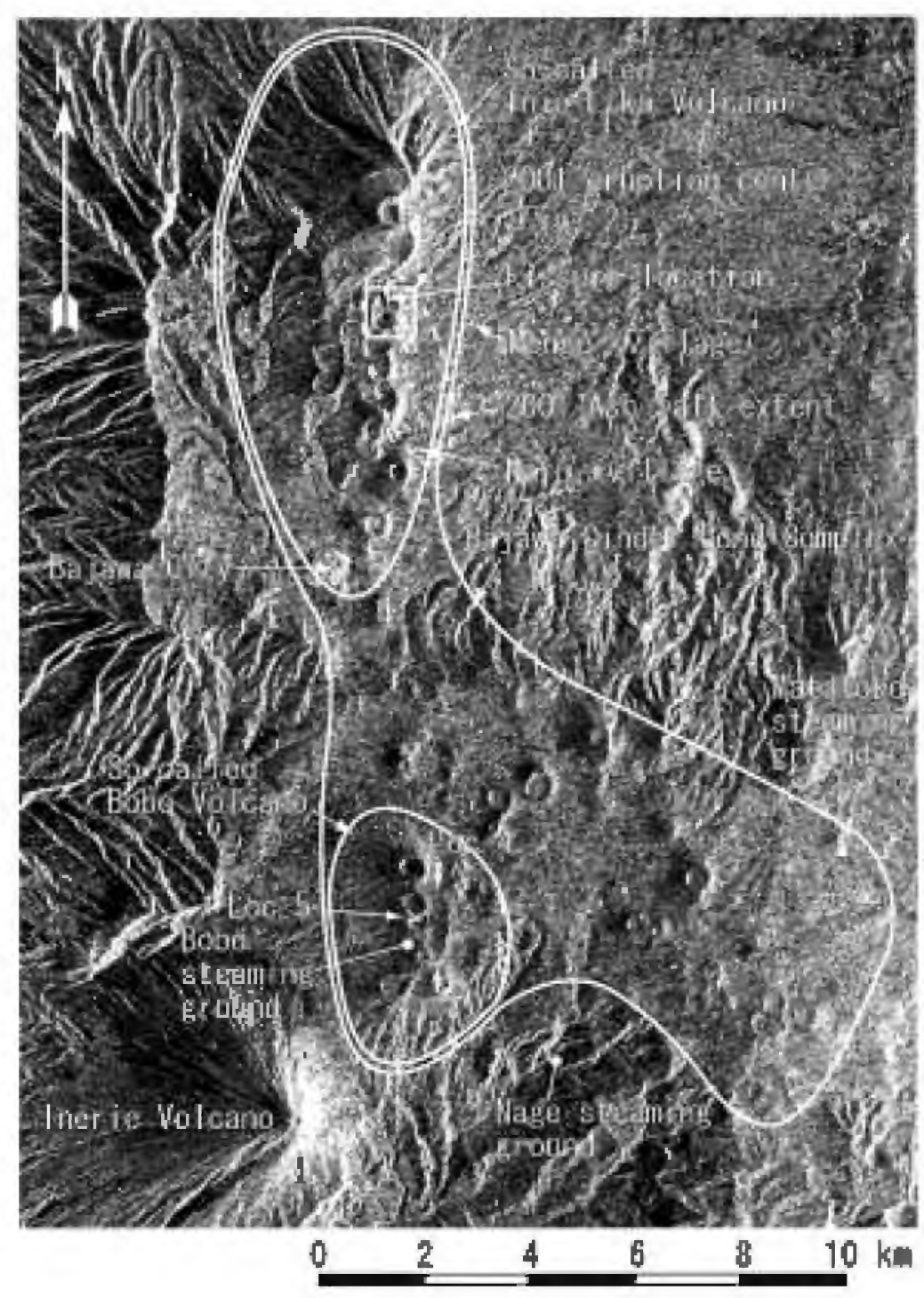

Fig. 1 JERS-1 SAR imagery, Inie Lika volcano, 2001 ash fall extent and the Bajawa Cinder Cone Complex (Copyright: METI/NASDA). 
with ash clouds $300-1000 \mathrm{~m}$ above the crater rim and sounds of thunder. These three events might have been the climactic events of the 2001 eruption. The ash emission continued until January 16, 2001 with ash clouds 100-1000 $\mathrm{m}$ above the crater rim.

Ahmad (2001a) also described that explosions produced both ash and lapilli during January 16-22, 2001. However, when we visited the eruption center on January 21 and 22, 2001, we only saw voluminous steam emissions. Many local residents in Menge Village, the best observation point, told us that the eruption events continued for five or six days since its incipience. Therefore, we think that the descriptions of the eruptions during January 1722 are not accurate, and explosive eruptions with ejecta production probably were confined to January 11-16, 2001.

January or February is the peak of the rainy season for this region. It rains every afternoon so that the primary ash fall deposits were easily washed away. The thickness of primary ash fall deposits is difficult to estimate for this reason, particularly areas of very thin accumulation. Actually, we never saw ash fall deposits in Bajawa City as of
January 20, 2001. The extent of ash fall deposits in Fig. 1 was drawn by the observations on January 21-22, 2001, and the maximum thickness of the ash fall deposits was $20 \mathrm{~cm}$ at the eruption center. The primary extent of ash fall deposits might have been much wider than the area shown in Fig. 1.

Whether the eruption was phreatic or phreatomagmatic is still not determined. We need further detailed study on the ash sample but juvenile ejecta may not be easy to distinguish from pre-existing ejecta because of the very fine ash. Whereas, many local residents observed a bright flare phenomena during the eruptions, suggesting a high possibility of an phreato-magmatic eruption. The formation of the fissure also supports the phreato-magmatic eruption as discussed below.

\section{Morphological change at the 2001 eruption center}

Figure 2 shows a sketch map of the 2001 eruption center at the Inie Lika volcano as of July 20, 2001 where the elevation contours represent the preeruption topography on a $12.5 \mathrm{~m}$ increment (Badan

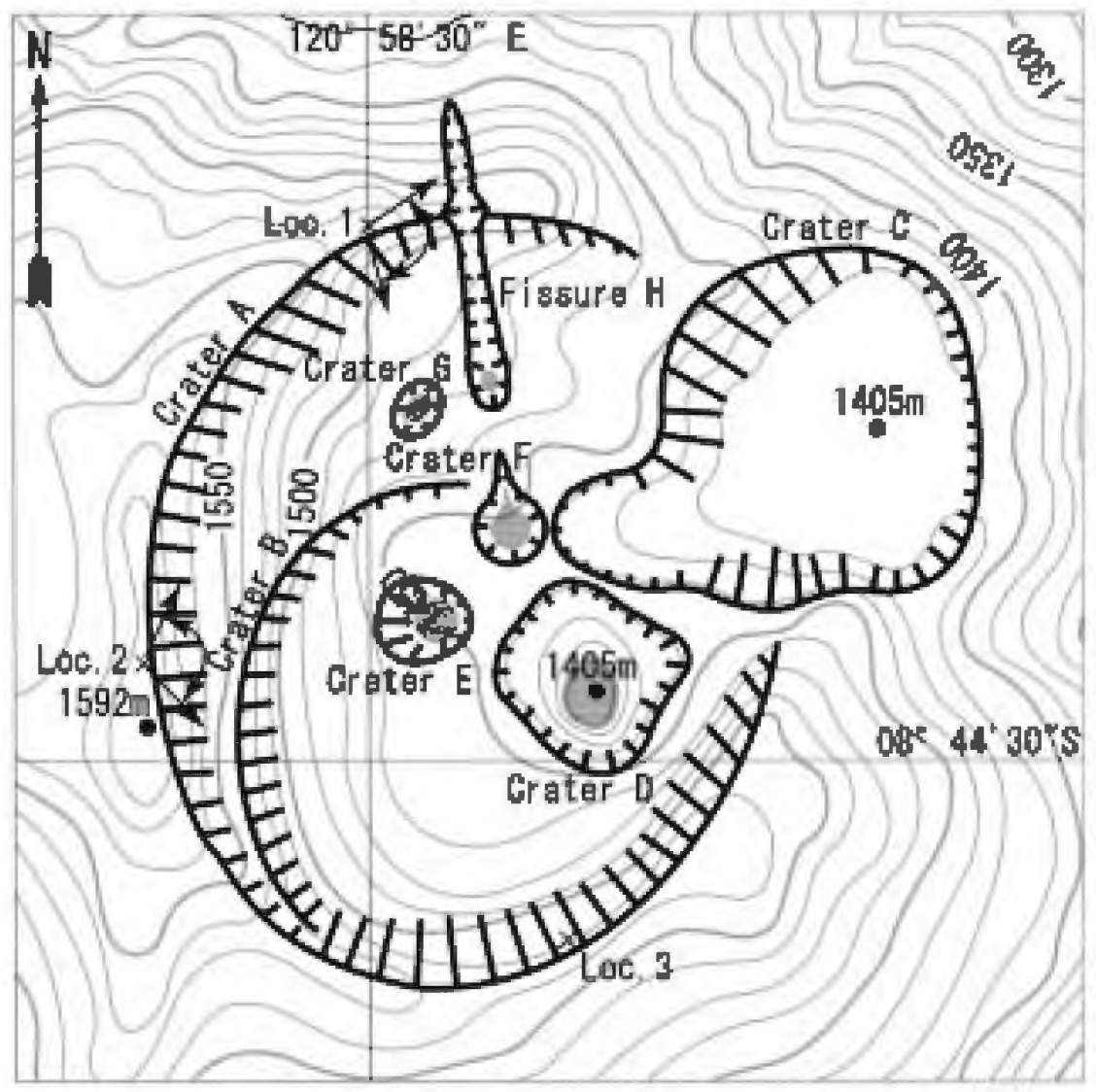

Fig. 2 Sketch map of the 2001 eruption center of the Inie Lika volcano as of July 20, 2001. Elevation contours represent the pre-eruption topography on a 12.5 $m$ increment (Badan Koordinasi Survey dan Pemetaan Nasional, 1993). 


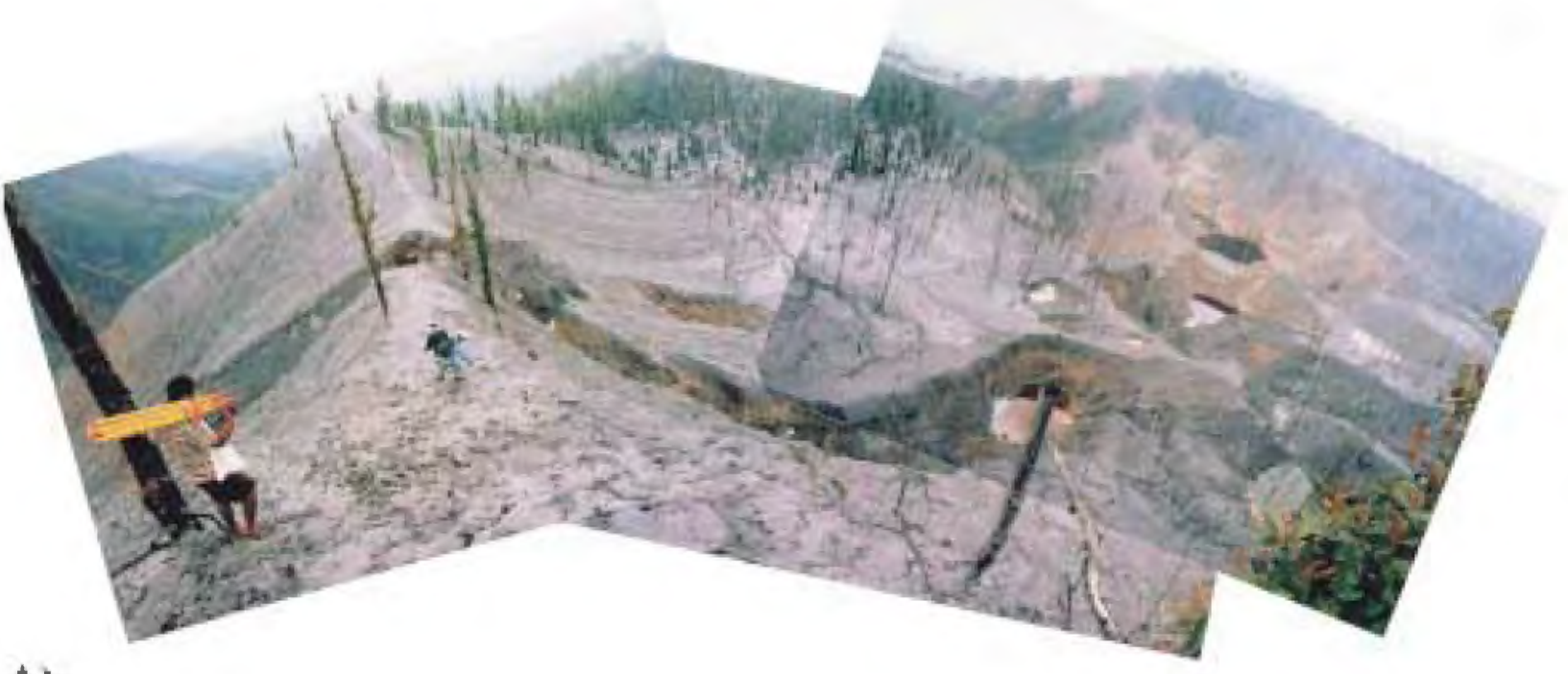

A)

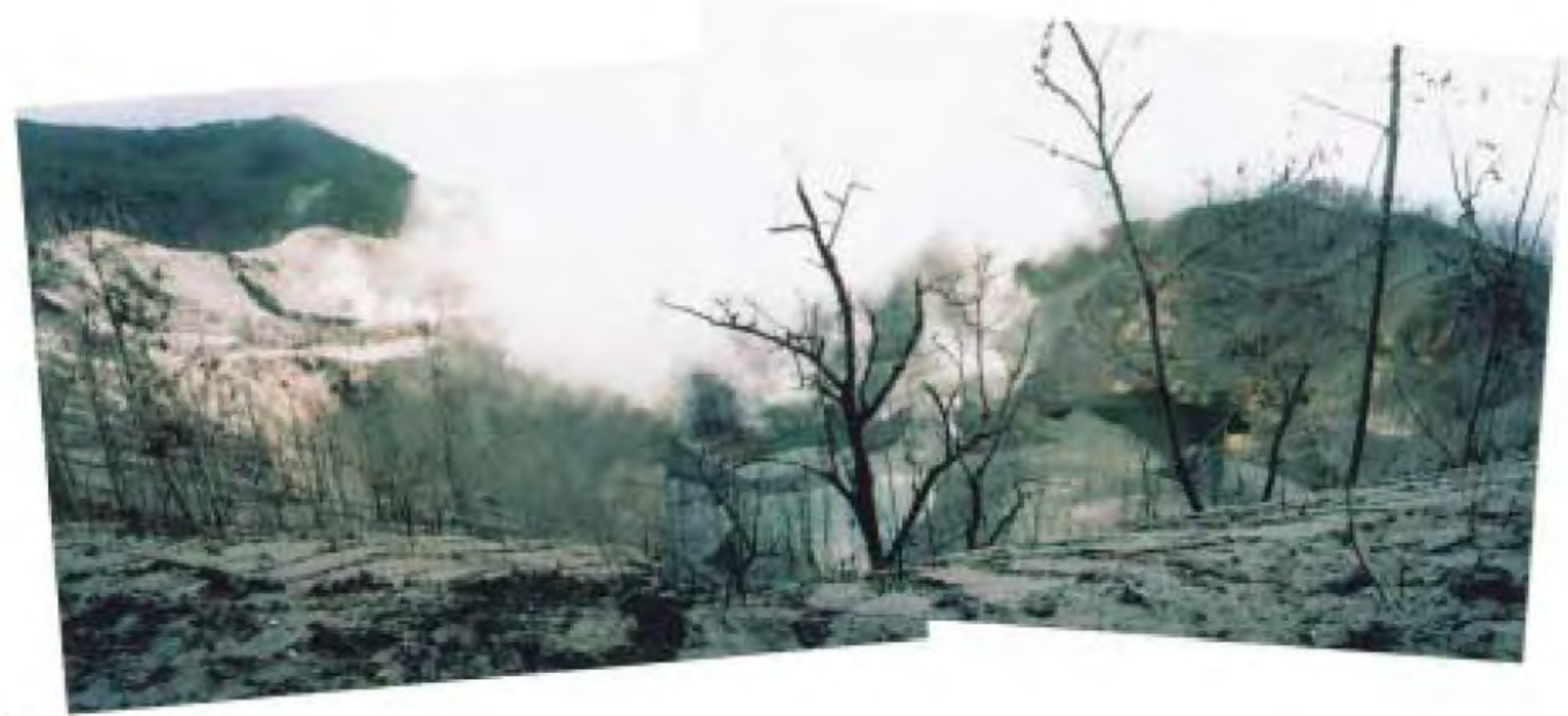

B)

Fig. 3 Photographs of the 2001 eruption center of the Inie Lika volcano. A) Photograph taken from the Loc. 1 in Fig. 2 on July 20, 2001. The photograph was distorted by a fish-eye effect. Refer to an undistorted configuration in Fig. 2. B) Photograph taken from Loc. 2 in Fig. 2 on January 22, 2001. 


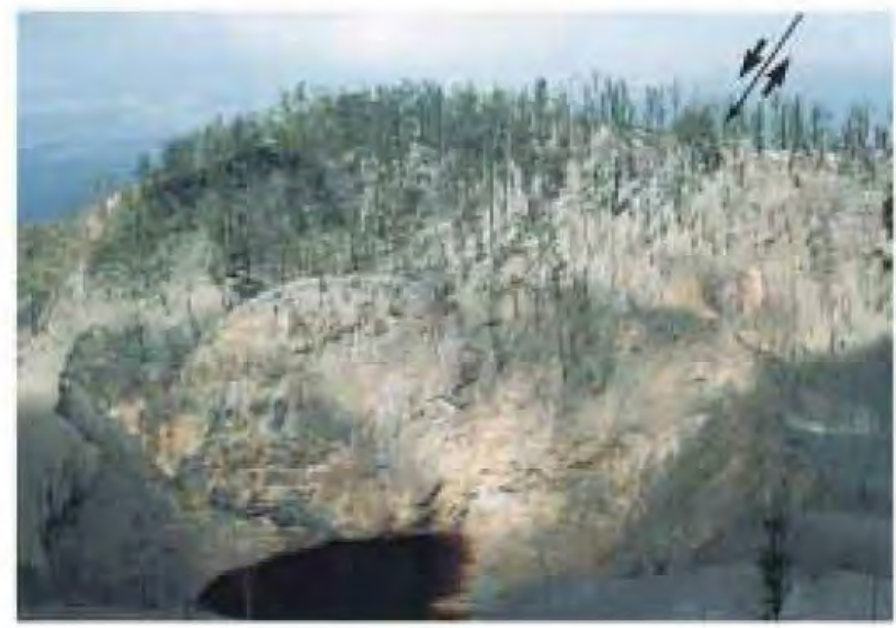

A)

Fig. 4 Photographs of the rifting features. A) A normal fault at Loc. 3 in Fig. 2 on the southern crater rim of the 2001 eruption center of the Inie Lika volcano. B) A N-S fissure remnant at Loc. 5 in Fig. 1 on the Bobo volcano.

Koordinasi Survey dan Pemetaan Nasional, 1993). Craters A, B and C are relatively older features that might have been formed during the growth of the cinder cone edifices. Their age range is from a $160 \mathrm{Ka}$ (Takashima et al., 2002, this volume) to the pre-historic time. Crater D was formed by the 1905 phreatic eruption (Neumann van Padang, 1951) and reactivated by the 2001 eruption (Ahmad, 2001a).

Figure 3A shows a photograph of the 2001 eruption center taken on July 20, 2001. Craters E, F, G and fissure $\mathrm{H}$ newly appeared by the 2001 eruption and might have played a major role as vents for the eruption. The fissure $\mathrm{H}$ trends in a $\mathrm{N} 16 \mathrm{~W}$ direction and is about $300 \mathrm{~m}$ long. The cross section of the fissure is between $\mathrm{V}$ - and U-shapes and is about 20 $\mathrm{m}$ wide at the top (Fig. $3 \mathrm{~A}$ ). The crater $\mathrm{F}$ is isolated from the fissure $\mathrm{H}$, but the shape and location also seem to be a southern extension of the fissure $\mathrm{H}$ (Figs. 2 and 3A). Because we have not observed the explosive eruption, we cannot specify which crater or fissure was the most active at the time of the explosive eruption. Figure $3 \mathrm{~B}$ shows a photograph of the 2001 eruption center taken on January 22, 2001, where the most active steam emission occurred along the southern end of the fissure $\mathrm{H}$, and subordinate emissions sporadically occurred at the northern part of the fissure $\mathrm{H}$ and crater $\mathrm{F}$. One idea is that the explosive eruption also occurred in a similar manner. Figure 4A shows a normal fault observed on the southern rim of the older Crater A that is situated on the southern extension of the fissure $\mathrm{H}$ and crater $\mathrm{F}$. Therefore, this fault might have also been caused by the fissure forming activity during the 2001 eruption and indicates that the place was also constrained by a force of the tensile

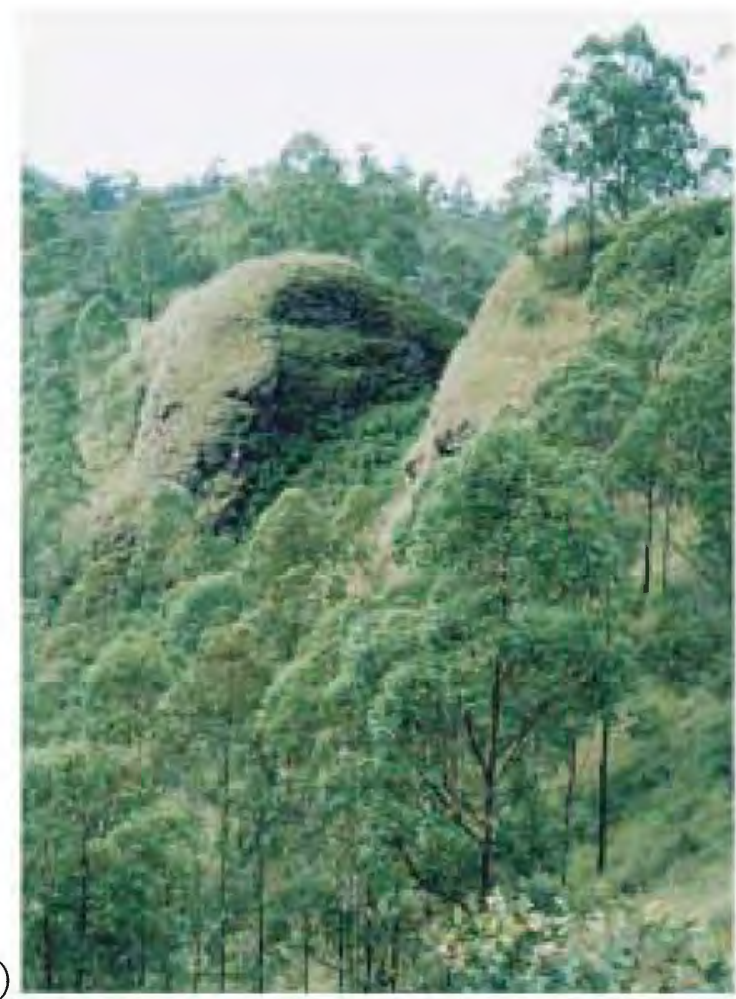

rifting.

\section{Discussion}

Based on the direct observations of the growing process of numerous cinder cones in the world, Wood (1980) summarized that the eruption usually started with the opening of the fissures and weak venting of gases, followed within hours by intense eruptions of large amounts of juvenile pyroclastic material. The 2001 eruption of Inie Lika volcano was too minor in scale to compare with the growth of cinder cones, but is basically similar to the general process and allowed us to observe the primary fissure because of the small amounts of ejecta.

Fissure formation is considered to reflect the surface extension due to various forces, and the fissure formation by the magmatic eruption is normally ascribed to a magmatic dike invasion to a shallow depth. Figure 5 shows the surface lateral shift by the dike invasion calculated from the equations of Okada (1985). The position of the maximum lateral shift can estimate the location of the fissurebounding faults, providing the width of the fissure in a half space. Among various parameters for the equations, the position of the maximum lateral shift is mainly controlled by the depth of the upper tip of the dike, regardless of the thickness of the dike. Figure 5 reveals that the $20 \mathrm{~m}$ wide fissure is only expected when the upper tip of the dike reaches an extremely shallow depth near the surface, as 


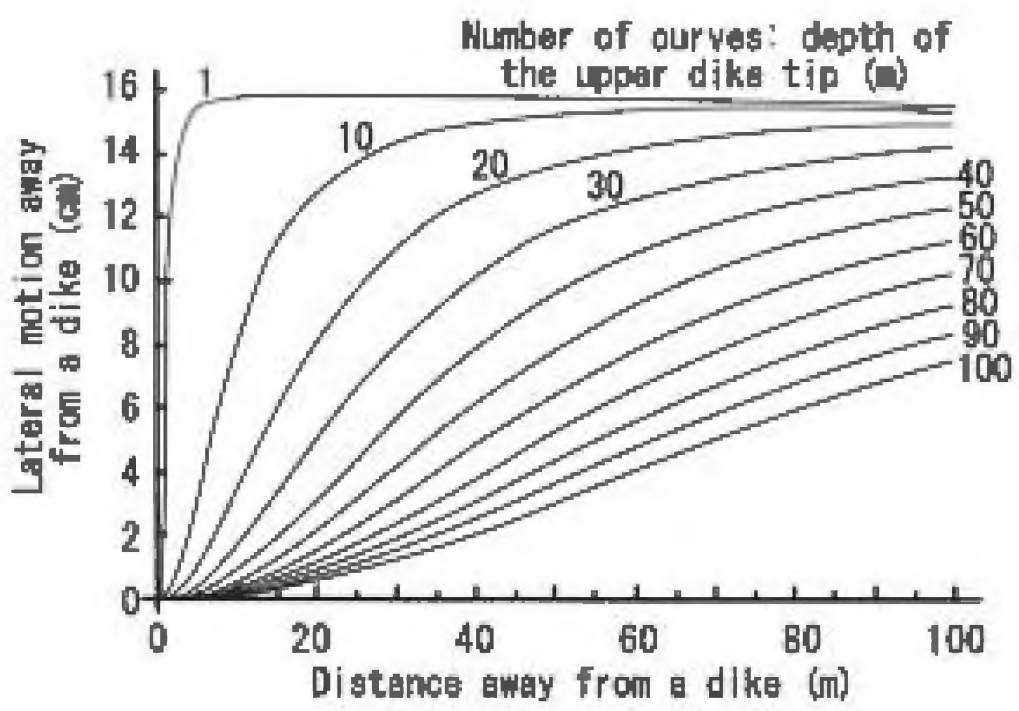

Fig. 5 Lateral shift component at the surface along a distance away from the dike plane in a two-dimensional half space calculated from the equations of Okada (1985). Input parameters are $500 \mathrm{~m}$ for the lateral length of the dike, $5000 \mathrm{~m}$ for the depth of the bottom of the dike and $0.5 \mathrm{~m}$ for the thickness of the dike.

indicated by the eruption. The $\mathrm{N} 16^{\circ} \mathrm{W}$ direction of the fissure represents the present-day maximum horizontal compressive stress axis in this region. This direction is slightly different from the known NNE motion of the Indian-Australian plate subduction, but is consistent with en echelon nature of the Lesser Sunda Islands (Muraoka, 1989).

Based on the geological surveys before the 2001 eruption, we assumed that the Bajawa Cinder Cone Complex was composed of a radial dike complex at a depth, being a major geothermal heat source serving for the present geothermal fields in the surrounding areas (Muraoka et al., 1999a, 1999b, 2000a, 2000b, 2000c, 2001a). This idea is, thus, supported by the 2001 fissure-forming eruption because the fissure formation preferably requires a magmatic dike invasion into a shallow depth and the eruption guarantees thermal potentials still stored in its magmatic source. When we think about the growing processes of the main edifices of the Bajawa Cinder Cone Complex, many fissures might have appeared due to dike invasions. An elongated crater of the eastern flank of the Bobo volcano marked as Loc. 4 in Fig. 1 may be some sort of fissure. However, even if fissures have once appeared, the growing cinder cone edifices will soon cover them. Therefore, we cannot observe many fissures in the present surface of the Bajawa Cinder Cone Complex. The fissures induced by post-cinder cone dikes that could have penetrated the cinder cone edifices may only be preserved at the surface like the fissure formed by the 2001 eruption. We have in fact observed a similar sort of fissure at the summit of the Bobo volcano of the Bajawa Cinder Cone Complex as shown in Fig. 4B. Thus, dikes and fissures might have played the most important role in the formation process of the Bajawa Cinder Cone Complex.

Acknowledgements: This work was supported by ODA funds of the Ministry of Economy, Trade and Industry (METI). We thank Dr. Akira Takada for his kind help on the calculation of surface deformation by dike invasion and constructive comments. We are grateful to the many researchers from the Directorate of Mineral Resources Inventory (DMRI) and Directorate of Volcanology and Geological Hazard Mitigation (the former Volcanological Survey of Indonesia) for their kind support during the field works.

\section{Reference}

Ahmad, D. (2001a) Explosions eject tephra in first eruption since 1905. Volcanic Activity Reports, 25, 12, http://www.volcano.si.edu/ gvp/volcano/region06/sunda/inielika/var. htm\#2512.

Ahmad, D. (2001b) Explosive activity declines; new image of the summit area. Volcanic Activity Reports, 26, 01, http://www.volcano.si.edu/gvp/volcano/region06/sunda/ inielika/var.htm\#2601.

Badan Koordinasi Survey dan Pemetaan Nasional (1993) Topographic Map 1: 25,000, Lokangeko. Badan Koordinasi Survey dan Pemetaan Nasional.

Muraoka, H. (1989) Reconnaissance for geology and gold ore deposits in Lesser Sunda 
Islands, South Pacific Ocean. Chishitsu (Geological) News, no.423, 35-42 (in Japanese).

Muraoka, H., Nasution, A., Urai, M. and Takahashi, M. (1998) A start of the "Research Cooperation Project on Exploration of Small-scale Geothermal Resources in Remote Islands in Indonesia", Chishitsu (Geological) News, no.521, 34-48 (in Japanese).

Muraoka, H., Nasution, A., Urai, M., Takahashi, M. and Takashima, I. (1999a) Regional geothermal geology of the Ngada District, central Flores, Indonesia. 1998 Interim Rept., Research Cooperation Project on the Exploration of Small-scale Geothermal Resources in the Eastern Part of Indonesia, Geol. Surv. Japan, 17-46.

Muraoka, H., Nasution, A., Urai, M., Takahashi, M. and Takashima, I. (1999b) A geothermal regime constrained by dikeshaped magma in Bajawa, Flores, Indonesia. In: Abstracts of 1999 Annual Meeting of Geothermal Research Society of Japan, p.A43 (in Japanese).

Muraoka, H., Nasution, A., Urai, M., Takahashi, M. and Takashima, I. (2000a) Regional geothermal geology of the Ngada District, central Flores, Indonesia. 1999 Interim Rept., Research Cooperation Project on the Exploration of Small-scale Geothermal Resources in the Eastern Part of Indonesia, Geol. Surv, Japan, 15-25.

Muraoka, H., Nasution, A., Urai, M., Takahashi, M. and Takashima, I. (2000b) Regional geothermal geology of the Ngada District, central Flores, Indonesia. Proceedings of World Geothermal Congress 2000, Beppu and Morioka, Japan, 1473-1478.

Muraoka, H., Nasution, A., Urai, M., Takahashi, M. and Takashima, I. (2000c) Homogeneous, calc-alkaline and dike-shaped magma beneath numerous cinder cones, Bajawa, Flores, Indonesia. In: Abstract of IA VCEI General Assembly 2000, Bali, p.15.

Muraoka, H., Nasution, A., Urai, M.,
Takahashi, M. and Takashima, I. (2001) Magmatic heat source of the Bajawa geothermal field, central Flores, Indonesia. Proceedings of $22^{\text {nd }}$ Annual PNOC-EDC Geothermal Conference, Makati, Philippines, 101-109.

Muraoka, H., Nasution, A., Urai, M., Takahashi, M., Takashima, I., Simanjuntak, J., Sundhoro, H., Aswin, D., Nanlohy, F., Sitorus, K., Takahashi, H. and Koseki, T. (2002) Tectonic, volcanic and startigraphic geology of the Bajawa geothermal field, central Flores, Indonesia. Bull. Geol. Surv. Japan, 53, 109-138.

Neumann van Padang, M. (1951) Inie Lika. In International Volcanological Association ed., Catalogue of the Active Volcanoes of the World Part I, Catalogue of the Active Volcanoes of Indonesia, International Volcanological Association, 174-176.

Okada, Y. (1985) Surface deformation due to shear and tensile faults in a half-space. Bull. Seismol. Soc. Am., 75, 1135-1154.

Pribadi, A., Kartadinata, M.N., Surmayadi, M. and Haerani, N. (2000) Geological Map of Inie Lika Volcanic Complex, Flores, East Nusatenggara 1: 25,000. Volcanological Survey of Indonesia.

Takashima, I., Nasution, A. and Muraoka, H. (2002) Thermoluminescence dating of volcanic and altered rocks in the Bajawa geothermal area, central Flores Island, Indonesia. Bull. Geol. Surv. Japan, 53, 139146.

Urai, M., Muraoka, H. and Nasution, A. (2002) Satellite remote sensing data and their interpretations for geothermal applications: A case study in the Ngada District, central Flores, Indonesia. Bull. Geol. Surv. Japan, 53, 99-108.

Wood, C.A. (1980) Morphometric evolution of cinder cones. J. Volcanol. Geotherm. Res., 7, 387-413.

Received October 9, 2001

Accepted February 21, 2002 


\title{
インドネシア・フローレス島中部イネリカ火山の割れ目を形成した 2001 年噴火 \\ 村岡洋文・安川香澄・浦井 稔・高橋正明・Asnawir NASUTION・高島 勲
}

\begin{abstract}
要旨
インドネシア・フローレス島のイネリカ火山に抽いて 2001年 1月 11-16 日に 95 年間の静穏期を経て マグマ水蒸気噴火が起こった。この噴火とその結果生じた噴火割れ目について記述した。イネリカ火山 は北北西一南南東方向に $16 \mathrm{~km}$ にわたって伸びるバジャワ噴石丘群の北部を構成している。噴火開始 以降，火山灰降下は 6 日間続き, 水蒸気放出は 2 ヶ月間続いた。特筆すべき点は, この噴火の結果, $\mathrm{N} 16^{\circ} \mathrm{W}$ 方向に伸びる幅約 $20 \mathrm{~m}$, 長さ約 $300 \mathrm{~m}$ の噴火割れ目が形成されたことである.これは地下浅 部に薄い岩脈状マグマが侵入して生じた伸張性割れ目であると推定される.
\end{abstract}

